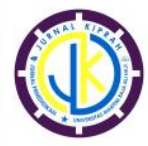

http://ojs.umrah.ac.id/index.php/kiprah

p-ISSN 2354-7278 | e-ISSN 2580-6947

\title{
Pengembangan Bahan Ajar Bernuansa Etnomatematika dengan Permainan Tradisional Banyumas pada Sekolah Dasar
}

\author{
Desi Setiyadi* \\ Pendidikan Guru Madrasah Ibtidaiyah, Fakultas Tarbiyah dan Keguruan, Institut Daarul Qur'an Jakarta, \\ Tangerang, Indonesia
}

Pengiriman: 14/04/2021; Diterima: 08/06/2021; Publikasi: 29/06/2021

DOI: 10.31629/kiprah.v9i1.3213

\begin{abstract}
Abstrak
Penelitian ini bertujuan mengembangkan bahan ajar bernuansa etnomatematika dengan permainan tradisional pada sekolah dasar. Secara lebih detail dalam penelitian ini akan diungkapkan 1) hasil observasi penggunaan bahan ajar dalam pembelajaran matematika kelas IV, 2) hasil pengembangan bahan ajar matematika bernuansa etnomatematika dengan permainan tradisional, 3) penilaian tim validator untuk pengembangan bahan ajar matematika, 4) pengaruh bahan ajar matematika bernuansa etnomatematika dengan permainan tradisional terhadap prestasi belajar, 5) penilaian dari pengguna langsung yaitu guru dan peserta didik terhadap bahan ajar matematika bernuansa etnomatematika dengan permainan tradisional. Populasi dalam penelitian ini adalah siswa kelas IV SD di UPK Kebasen. Teknik pengumpulan data berupa tes, observasi, validasi tim ahli, penilaian tim guru, dan kuisioner peserta didik. Berdasarkan hasil penelitian disimpulkan bahwa 1) hasil dari observasi dalam menggunaan bahan ajar terdapat beberapa kelemahan bagian materi dan soal latihan yang perlu diperbaiki, 2) pengembangan bahan ajar matematika bernuansa etnomatematika dengan permainan tradisional menggunakan model 4-D merupakan salah satu cara yang dapat digunakan dalam memperbaiki bahan ajar yang ada, 3) penilaian dari tim validator menunjukkan skor sebesar 4,77 dengan kategori sangat valid, 4) prestasi belajar menggunakan bahan ajar bernuansa etnomatematika dengan permainan tradisional lebih dari KKM yaitu 69, 5) hasil penilaian dari tim guru menghasilkan skor 4,834 dengan kategori sangat baik, dan respon peserta didik mendapatkan 93,33\% dengan kategori sangat setuju. Kesimpulan dalam penelitian yaitu bahan ajar matematika bernuansa etnomatematika dengan permainan tradisional Banyumas dapat digunakan bahan ajar di sekolah dasar.
\end{abstract}

Kata kunci: Bahan Ajar; Etnomatematika; Permainan Tradisioal Banyumas

\begin{abstract}
This study aims to develop teaching materials with ethnomathematical nuances with traditional games in elementary schools. In more detail, this study will reveal 1) the results of observations of the use of teaching materials in mathematics learning for grade IV , 2) the results of developing ethnomathematical teaching materials with traditional games, 3 ) assessment of the validator team for the development of mathematics teaching materials, 4) the influence of teaching materials ethnomathematical nuanced mathematics with traditional games on learning achievement, 5) assessments from direct users, namely teachers and students, on ethnomathematical mathematics teaching materials with traditional games. The population in this study were fourth grade elementary school students at UPK Kebasen. Data collection techniques in the form of tests, observations, expert team validation, teacher team assessments, and student questionnaires. Based on the results of the study, it was concluded that 1) the results of observations in using teaching materials there were several weaknesses in the material and practice questions that needed to be improved, 2) the development of ethnomathematical teaching materials with traditional games using the 4-D model is one way that can be used in improve the existing teaching materials, 3) the assessment from the validator team shows a score of 4.77 with a very valid category, 4 ) learning achievement
\end{abstract}


using ethnomathematical teaching materials with traditional games more than the KKM is 69. 5) the results of the assessment from the teacher team produce a score 4,834 in the very good category, and the response of students getting $93.33 \%$ in the category of strongly agree. The conclusion in the study is that the teaching materials of mathematics with ethnomathematics nuances with traditional Banyumas games can be used as teaching materials in elementary schools.

Keywords: Banyumas Traditional Games; Ethnomatematics; Teaching Materials

\section{PENDAHULUAN}

Teknologi dalam bidang pendidikan merupakan integrasi dari berbagai teknologi informasi dan komunikasi untuk meningkatkan kapasitas lingkungan pembelajaran yang lebih lancar (Azzam, 2020). Menurut Sumiarsi (2015) setelah melakukan pembelajaran, guru sebaiknya melakukan kegiatan evaluasi sehingga mendapatkan kritik dan saran yang membangun dalam pembelajaran. Setiyadi (2018) menyatakan bahwa potensi diri peserta didik dapat terlihat dengan melakukan kegiatan pembelajaran. Hal tesebut mendukung dalam proses memahami minat, kreativitas, dan daya pikir peserta didik. Pembelajaran yang menarik dapat mendorong peserta didik menjadi lebih mengembangkan pola pikir yang kritis dalam kehidupan mereka. Ansari \& Khan (2020) menyatakan pendidikan dilaksanakan tidak hanya di dalam ruang kelas saja, namun juga berada di lingkungan sekitar dan terjadi pada otak peserta didik itu sendiri.

Kusumam, Mukhidin \& Hasan (2016) menyatakan fasilitator dalam pendidikan yaitu guru yang merupakan salah satu komponen yang penting dalam peserta didik menyerap pendidikan yang bermutu. Hal ini tentunya guru dituntut selalu memberikan pelayanan prima dalam pembelajaran salah satunya yaitu dalam pembuatan bahan ajar.

Pandangan peserta didik tentang mata pelajaran matematika masih tergolong negatif. Ditunjukkan dengan anggapan matematika sebagai mata pelajaran yang sukar dipelajari. Namun, pada akhirnya matematika merupakan ilmu yang pasti digunakan kehidupan seharihari. Pendapat tersebut muncul karena hasil observasi menunjukkan sebagian besar guru hanya menyuruh peserta didik untuk mengerjakan latihan-latihan soal terus tanpa diimbangi dengan kemampuan pemecahan masalah yang benar dalam menyampaikan materi pelajaran. Supardi (2012) menyatakan faktor utama menyebabkan mutu pembelajaran matematika rendah yaitu guru kurang memotivasi peserta didik dan perangkat pembelajaran.

Keberadaan bahan ajar matematika menjadi salah satu perangkat pembelajaran di SD. Tentunya membantu peserta didik dalam memahami materi dan dapat digunakan sebagai bahan berdiskusi. Hasil dari observasi yang dilakukan bulan Januari 2020 tentang bahan ajar matematika kelas IV yang digunakan di SD saat proses bahan ajar yang digunakan menghasikan beberapa temuan yaitu 1) materi pada bahan ajar matematika terlalu sedikit, sehingga berdampak kepada peserta didik sebagai pengguna masih banyak yang merasa kebingungan, 2) kalimat motivasi yang digunakan sudah cukup baik, kooperatif mengajak peserta didik untuk belajar, 3) bentuk soal latihan dalam bahan ajar tidak berubah dalam setiap tahunnya (monoton), 4) cetakan bahan ajar yang hitam putih (tidak berwarna) sehingga peserta didik kurang tertarik, 5) kurang minatnya peserta didik tentang belajar matematika.

Pembelajaran yang menggunakan bahan ajar kontekstual akan membantu peserta didik dalam memahami materi yang disampaikan oleh guru. Hal ini sejalan dengan pendapat Al-Tabany (2017) tentang aspek kinerja peserta didik (contextual teaching and learning). Peranan guru hanya mediator siswa lebih aktif dan inovatif untuk merumuskan sendiri tentang kejadian yang berhubungan dengan fokus kajian kontekstual bukan tekstual. Hamalik dalam Harjanto (2008) menyatakan dalam pengembangan bahan ajar 
aspek-aspek berikut ini yaitu 1) konsep, 2) prinsip, 3) fakta, 4) proses, 5) nilai, 6) keterampilan.

Geni \& Hidayah (2017) menyatakan bahwa permasalahan belajar matematika yang dialami oleh peserta didik dapat untuk diselesaikan dengan bebagai cara dengan melihat lingkungan kehidupan dari peserta didik itu sendiri. Tentunya di dalamnya memerlukan sebuah inovasi pembelajaran yang mampu mendorong peserta didik membagun pengetahuan mereka. Kebudayaan yang hidup dan berkembang yang memuat matematika di masyarakat pada suatu daerah tertentu disebut etnomatematika (Yusuf, 2010).

Menurut Hammond dalam Setiyadi, Zaenuri \& Mulyono (2018) menyatakan bahwa salah satu unsur masyarakat yaitu norma atau aturan, kepercayaan, nilai, dan kebiasaan yang berlaku di masyarakat. Konsep bahan ajar matematika yang akan dibuat yaitu dengan nuansa etnomatematika dengan permainan tradisional. Shirley dalam Marsigit (2016) berpandangan bahwa sebaiknya media pembelajaran yang digunakan yaitu yang bersumber kepada kebudayaan yang berada di sekitar peserta didik.

\section{Kabupaten Banyumas merupakan} daerah di Jawa Tengah yang sudah lama terdengar di telinga kita. Hal ini tentunya terdapat berbagai macam budaya di daerah tersebut. Bentuk dari budaya yang dimaksud yaitu permainan tradisional. Setiyadi, et all (2018) menyatakan salah satu permainan yang berasal dari Banyumas yaitu engklek dan damdaman.

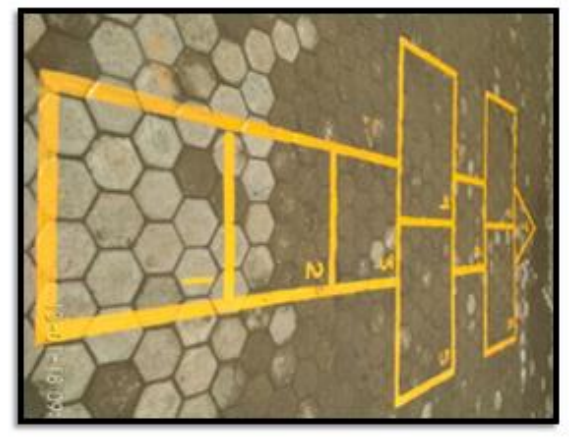

Gambar 1. Denah Permainan Engklek

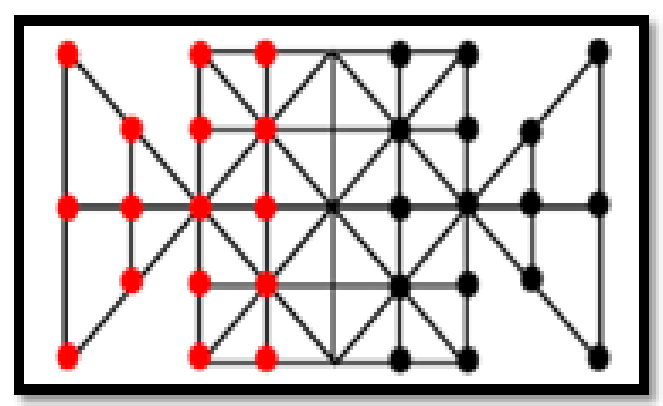

Gambar 2. Denah Permainan Dam-Daman

Berdasarkan identifikasi permasalahan di atas, maka tujuan dalam penelitian ini yaitu perlunya sebuah pengembangan bahan ajar matematika bernuansa etnomatematika dengan permainan tradisional di SD.

\section{METODE PENELITIAN}

Metode penelitian menggunakan eksploratoris sekuensial (kualitatif-kuantitatif). Pada penelitian kualitatif menggunakan metode observasi, wawancara dan dokumentasi, sedangkan penelitian kuantitatif berua tes dan non tes. Jenis penelitian yaitu research and development $(\mathrm{R} \& \mathrm{D})$. Hasil produk berupa bahan ajar matematika bernuansa etnomatematika dengan permainan tradisional pada SD. Menurut Tiagarajan, Semmel \& Semmel (1974) menyatakan bahwa pengembangan bahan ajar matematika model pengembangan 4-D dapat dilihat Gambar 3.

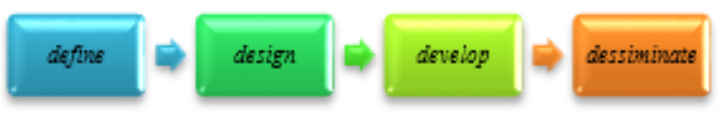

Gambar 3. Pengembangan model 4-D

Penelitian hanya sampai di tahapan develop dengan menggunakan percobaan dalam skala terbatas yaitu melihat pengaruh bahan ajar bernuansa etnomatematika dengan permainan tradisional terhadap prestasi belajar matematika. Uji coba skala terbatas dilaksanakan di SD wilayah UPK Kebasen. Metode pengumpulan data yaitu tes dan non tes. Tes berfungsi mengukur kemampuan peserta didik sebelum dan sesudah perlakuan. Non tes dapat dilihat dari Gambar 4. 


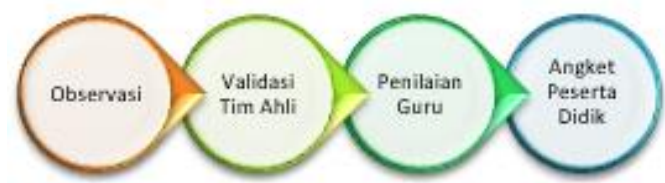

Gambar 4. Metode Pengumpulan data Non Tes

Uji coba instrumen berguna untuk memastikan instrumen valid dengan bantuan program anates uraian yang meliputi seperti Gambar 5.

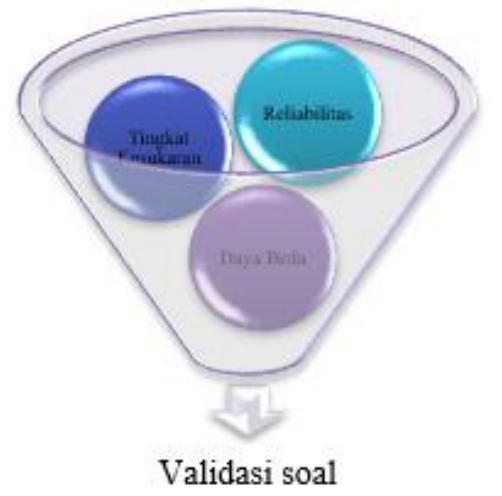

Gambar 5. Analisis Butir Soal

\section{HASIL DAN PEMBAHASAN}

Tahapan pengembangan bahan ajar sebaggai berikut. Tahap pertama yaitu pendefinisian (define) dengan melakukan analisis kebutuhan guru dan peserta didik dalam bahan ajar. Kegiatan yang dilakukan terdiri dari 1) observation, 2) interview, dan 3) penyebaran angket sehingga mendapatkan data lapangan yang benar. Pada tahapan ini dimulai dari analisis awal hingga akhir. Analisis awal berupa hasil observasi yang ditemukan di lapangan dan mengumpulan materi sebagai bahan pembuatan draft mentah 1, seperti, silabus, RPP, kompetensi inti, kompetensi dasar, materi, gambar dan animasi.

Pada tahapan design yang dilakukan membuat design cover dan kerangka isi bahan ajar. Pemilihan bahan materi, imajinasi dalam tahap ini sangat diperlukan guna menunjang ketertarikan peserta didik dalam belajar nantinya. Selain itu, berguna untuk menambah ruang di halaman bahan ajar. Desain awal bahan ajar meliputi desain sampul menggunakan design grafis cover dan isi menggunakan Microsoft Word 2010.
Kalimat yang berada di cover, berisikan tentang identitas penulis, logo lembaga, judul bahan ajar, gambar kegiatan permainan tradisional, identitas lembaga, dan kelas. Kesulitan dalam membuat cover saat pemilihan model, tata letak gambar dan warna yang dapat menarik perhatian peserta didik, serta dapat mewakili isi bahan ajar. Gambar 6 menunjukkan cover dari bahan ajar bernuansa etnomatematika dengan permainan tradisional di SD.

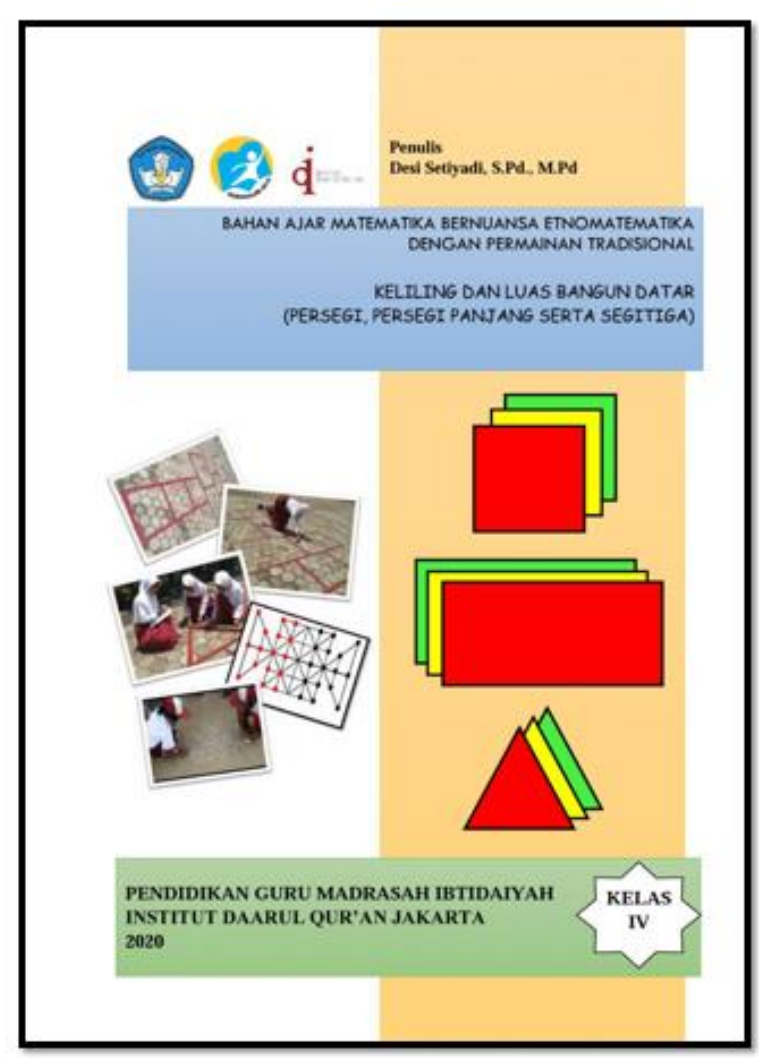

Gambar 6. Sampul Depan Bahan Ajar

Selanjutnya membuat KI dan KD K13 dan peta konsep sehingga tujuan dari bahan ajar dapat diketahui. Berikut ini Gambar 7 tentang tampilan KI dan KD. Proses pembelajaran bernuansa etnomatematika dengan permainan tradisional menjadi hal penting karena peserta didik akan belajar dengan masalah-masalah yang setiap harinya mereka jumpai yaitu beberapa permainan yang berada di Banyumas yaitu permainan engklek dan dam-daman dan dapat dilihat pada Gambar 8 pada pembelajaran 1. 


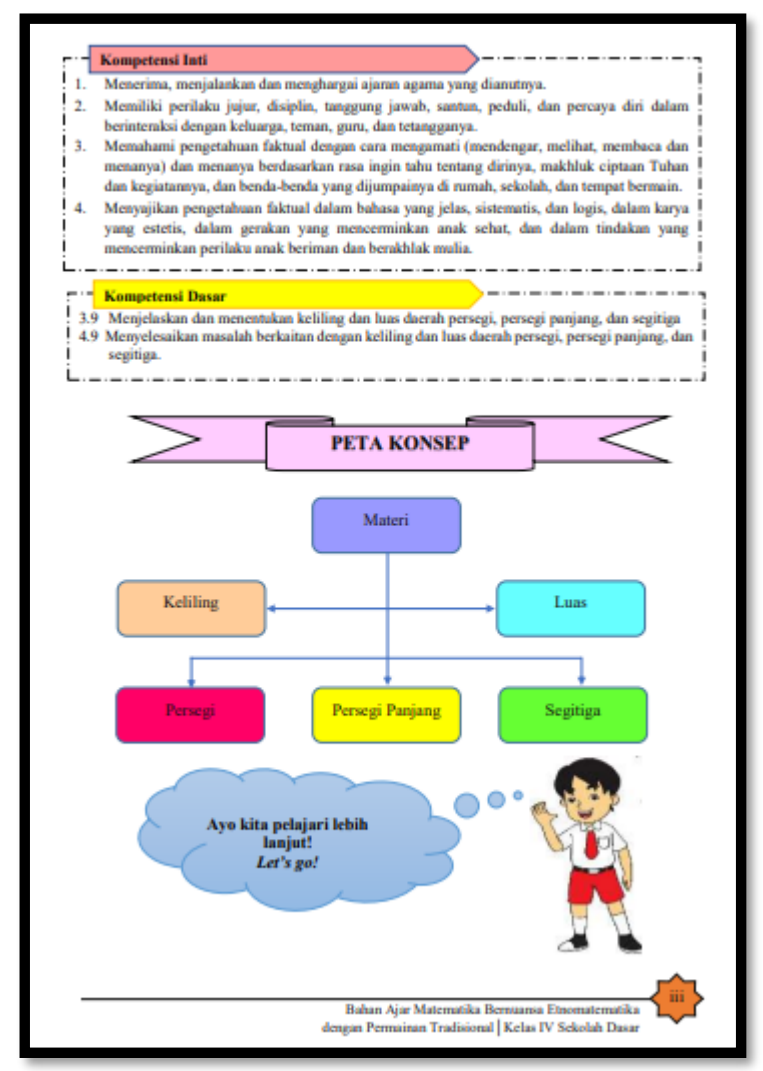

Gambar 7. KI, KD dan Peta Konsep

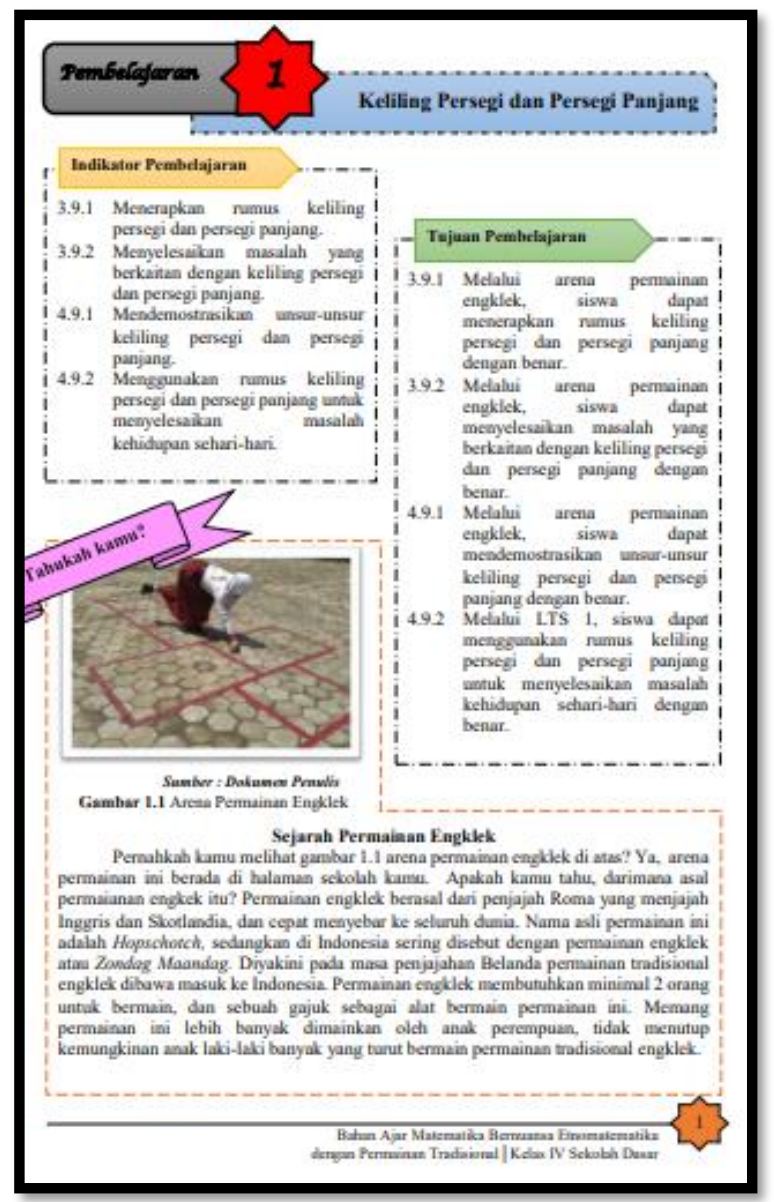

Gambar 8. Pembelajaran 1
Menurut Rudyanto, Kartikasari \& Pratiwi (2019) menyatakan budaya Jawa dapat dimanfaatkan untuk pembelajaran matematika yang bermakna. Kegiatan pada bahan ajar dapat dilihat pada Gambar 9 dan Gambar 10. Penggunaan arena permainan dam-daman dapat dijadikan sebagai sarana menghitung luas persegi, seperti terlihat pada Gambar 11.

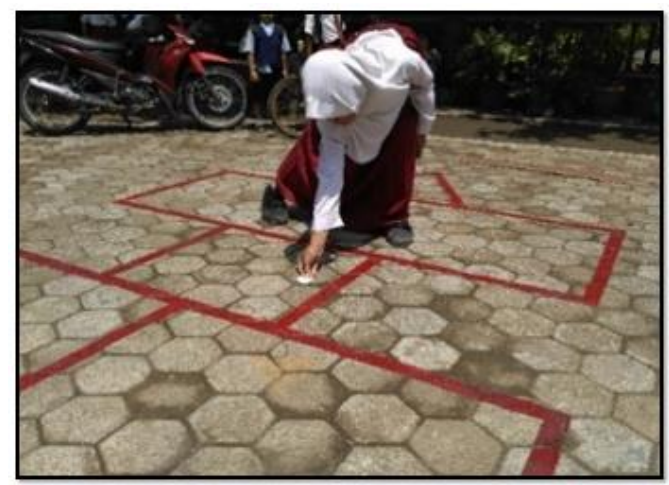

Gambar 9. Peserta Didik Bermain Engklek

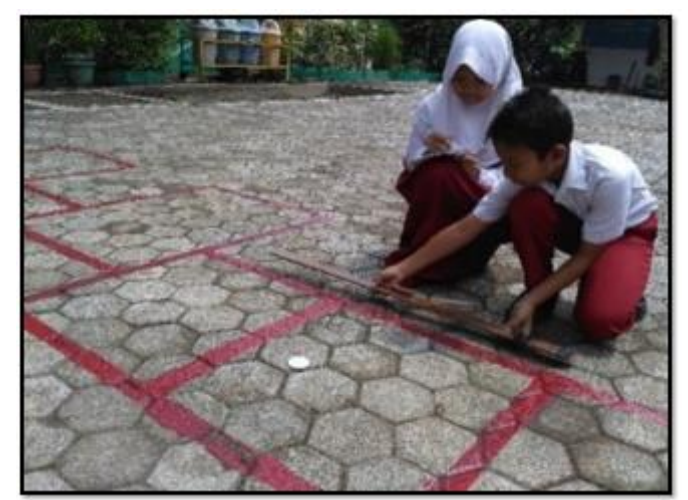

Gambar 10. Peserta Didik Mengukur Arena Engklek

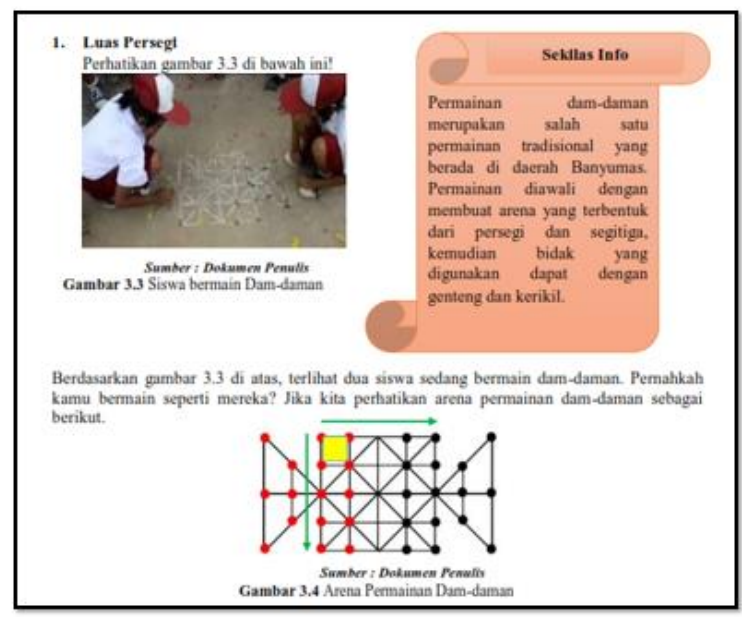

Gambar 11. Arena Dam-Daman untuk Menghitung Luas Persegi 
Tahapan selanjutnya yaitu develop. Bahan ajar yang dikembangkan memuat langkah-langkah tahapan kemampuan pemecahan masalah (TKPM) berdasarkan tahapan Polya dalam Wardani (2010) seperti Gambar 12.

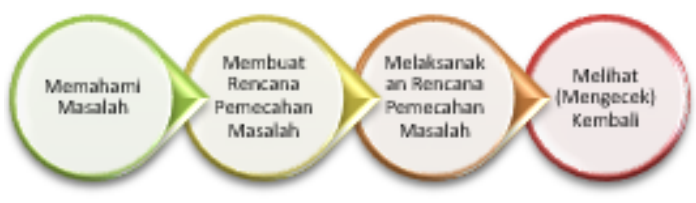

Gambar 12. Langkah TKPM

Shanti \& Agus (2015) menyatakan bahwa pendekatan kemampuan pemecahan masalah, peserta didik diwajibkan untuk mengidentifikasi masalah matematika. Hal ini berarti peserta didik untuk dapat menuliskan apa yang diketahui dan ditanyakan dalam permasalahan. Kemudian mampu menuliskan rumus penyelesaian untuk menyelesaikan masalah, dan memasukan angka ke rumus yang sudah tersedia dan menghasilkan jawaban yang diminta. Langkah terakhir yaitu mengecek kembali jawaban dengan cara yang lain. Dewi \& Kaltsum (2017) menyatakan alternatif yang dapat digunakan untuk menemukan solusi permasalahan yaitu dengan mengintegrasikan pengetahuan awal dan akhir yang diperoleh peserta didik.

Murniati, Mulyono \& Kharis (2017) menyatakan dalam TKPM, peserta didik diwajibkan untuk memahami, menuliskan, mengidentifikasi, dan menganalisis suatu masalah. Peserta didik diharapkan menyelesaikan soal-soal latihan yang diberikan oleh guru dengan benar. Gambar 13 contoh latihan soal pada bahan ajar.

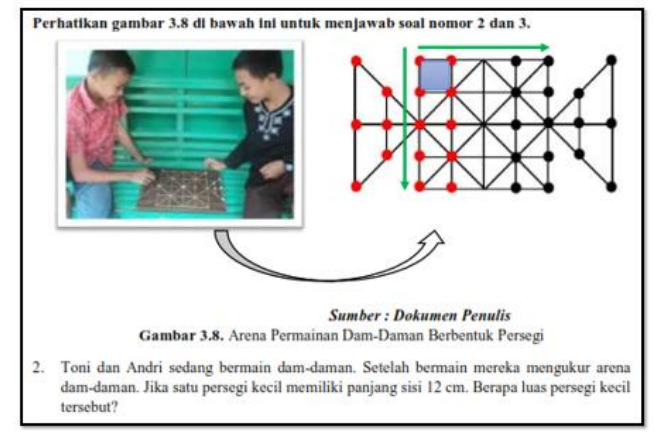

Gambar 13. Latihan Soal Menggunakan DamDaman
Langkah selanjutnya peserta didik dalam TKPM yang bernuansa etnomatematika dengan permainan tradisional. Peserta didik memahami contoh soal yang berhubungan dengan dapat dilihat pada Gambar 12. Kemudian membuat kalimat matematika sesuai dengan soal dan diintegrasikan dengan TKPM sesuai dengan Gambar 14.

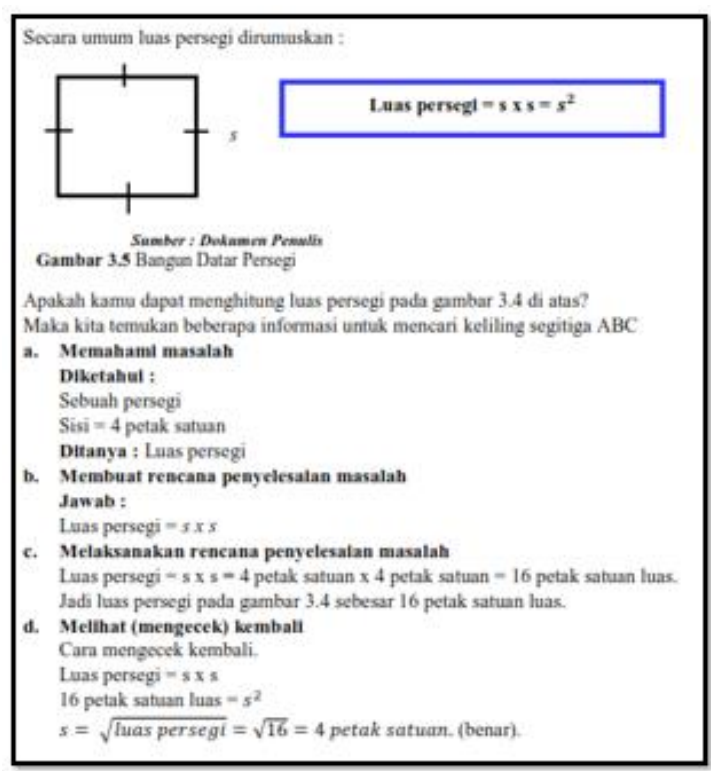

Gambar 14. Tahapan TKPM dalam Bahan Ajar

Validasi ahli terhadap bahan ajar matematika dilakukan oleh tim validator yang bertujuan untuk mengetahui kekurangan dan kelebihan pada bahan ajar, sehingga tercipta bahan ajar yang diharapkan sesuai kebutuhan peserta didik. Saran dari validator yaitu 1) perbaikan bahasa Indonesia dalam isi bahan ajar supaya lebih komunikatif, 2) penggunaan kalimat asing atau bahasa Jawa dapat ditulis dengan huruf miring (italic), 3) lebih bermain warna sehingga lebih menarik perhatian peserta didik, 4) kalimat matematika dapat dimunculkan dengan menggunakan gambar yang menarik, 5). Hasil validasi dari tiga orang yang terdiri dari ahli di bidang pendidikan dasar, ahli matematika dan ahli bahasa mendapatkan skor 4,77.

Hasil kuantitatif yang dilakukan pada kelas eksperimen dan kelas kontrol dapat dilihat pada Tabel 1. 
Tabel 1. Ketuntasan Kelas Eksperimen dan Kelas Kontrol

\begin{tabular}{lccllll}
\hline Kelas & $\mathrm{N}$ & $\bar{X}$ & Maks & Min & Tuntas & Presentase \\
\hline $\mathrm{E}$ & 33 & 87,12 & 100 & 73 & 33 & $100 \%$ \\
$\mathrm{~K}$ & 32 & 78,28 & 100 & 67 & 28 & $87,50 \%$ \\
\hline
\end{tabular}

Keterangan :

E : Kelas eksperimen menggunakan bahan ajar matematika bernuansa etnomatematika dengan permainan tradisional.

K : Kelas kontrol menggunakan bahan ajar di kelas.

$\mathrm{N} \quad$ : Jumlah siswa setiap kelas.

$\bar{X} \quad$ : Rata-rata skor.

Maks : Skor maksimal

Min : Skor minimal

Berdasarkan Tabel 1 diperoleh kesimpulan mean sebesar 87,12 dan semua peserta didik tuntas di atas KKM sebesar 69 pada kelas eksperimen, sedangkan pada kelas kontrol menghasilkan mean 78,28 dan tidak tuntas sebanyak 4 peserta didik. Berdasarkan Tabel 2 One Sampel T-Test pada kolom signifikansi (2-tailed) mendapatkan skor 0,000 $<0,05$ yang berarti $\mathrm{H}_{\mathrm{a}}$ diterima dapat disimpulkan prestasi belajar menggunakan bahan ajar bernuansa etnomatematika dengan permainan tradisional lebih dari KKM yaitu 69.

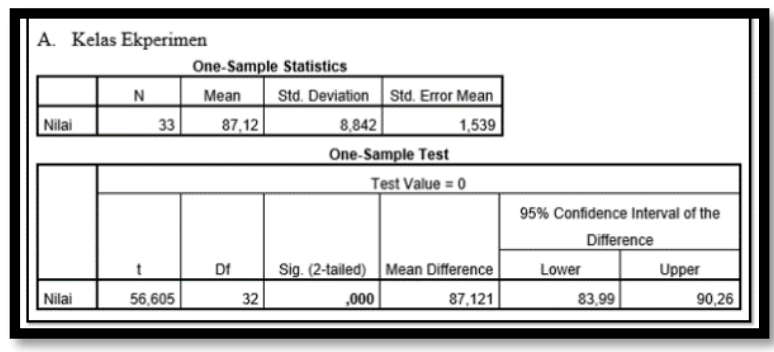

Gambar 15. Uji Rata-Rata

(One Sampel T-Test)

Penilaian dari tim guru dilakukan untuk mengetahui penilaian sebagai pengguna langsung pada bahan ajar. Aspek penilaian tim guru dapat dilihat pada Tabel 2.
Tabel 2. Aspek Penilaian Guru Terhadap Bahan Ajar

\begin{tabular}{cl}
\hline No. & \multicolumn{1}{c}{ Aspek } \\
\hline 1 & Penilaian \\
2 & Kebenaran Kosep Matematika \\
3 & Kedalaman Konsep \\
4 & Keluasan Konsep \\
5 & Kejelasan Kalimat \\
6 & Kebahasaan \\
7 & Penilaian Belajar \\
8 & Kerja Peserta Didik \\
9 & Keterlaksanaan \\
10 & Penampilan Fisik \\
\hline
\end{tabular}

Skor pada penilaian ini yang didapatkan sebesar 4,834 dan dikategorikan sangat baik (tanpa revisi) seperti Gambar 13.

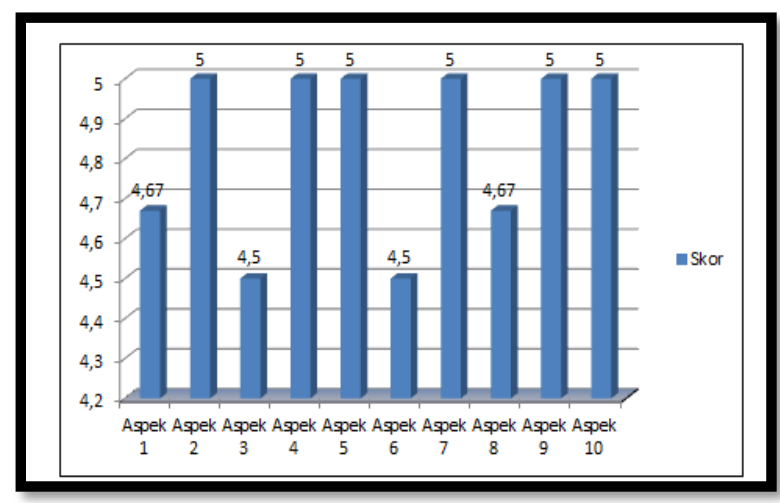

Gambar 16. Penilaian Guru

Berdasarkan hasil analisis kuisioner respon peserta didik tentang bahan ajar disimpulkan sebagai berikut, jumlah seluruh peserta didik sebanyak 30 orang yang terdiri dari 28 peserta didik memilih setuju dan 2 peserta didik yang memilih opsi tidak setuju. Data dikonsultasikan dengan rumus presentase angket respon peserta didik (PRS) sebagai berikut :

$$
\begin{aligned}
\text { PRS } & =\frac{A}{B} X 100 \% \\
& =\frac{28}{30} \times 100 \%=93,33 \%
\end{aligned}
$$

Keterangan :

PRS : Presentase Respon Peserta didik

A : Jumlah Peserta didik Setuju

B : Jumlah Peserta didik 
Berdasarkan hasil perhitungan PRS diperoleh skor 93,33\%, dan dapat dinyatakan sangat setuju. Supriyati, Zaenuri \& Sugiman (2015) menyatakan bahwa pembelajaran akan lebih bermakna dengan cara mengaitkan permasalahan dengan lingkungan peserta didik. Muzdalipah \& Yulianto (2015) menyatakan bahwa permainan tradisional yang berkembang mengandung konsep-konsep matematika. Oleh karena itu permainan tradisional tidak hanya untuk sekedar bermain saja, tetapi dapat sebagai bahan ajar peserta didik dalam belajar matematika untuk menambah pengetahuan.

\section{KESIMPULAN}

Berdasarkan hasil penelitian disimpulkan bahwa 1) hasil dari observasi dalam menggunaan bahan ajar terdapat beberapa kelemahan bagian materi dan soal latihan yang perlu diperbaiki, 2) pengembangan bahan ajar matematika bernuansa etnomatematika dengan permainan tradisional menggunakan model 4-D merupakan salah satu cara yang dapat digunakan dalam memperbaiki bahan ajar yang ada, 3) penilaian dari tim validator menunjukkan skor sebesar 4,77 dengan kategori sangat valid, 4) prestasi belajar menggunakan bahan ajar bernuansa etnomatematika dengan permainan tradisional lebih dari KKM yaitu 69,5) hasil penilaian dari tim guru menghasilkan skor 4,834 dengan kategori sangat baik, dan respon peserta didik mendapatkan 93,33\% dengan kategori sangat setuju. Kesimpulan dalam penelitian yaitu bahan ajar matematika bernuansa etnomatematika dengan permainan tradisional Banyumas dapat digunakan bahan ajar di sekolah dasar.

\section{UCAPAN TERIMAKASIH}

Kami mengucapkan terima kasih kepada pihak yang terkait khususnya di SD UPK Kebasen, Kabupaten Banyumas, Jawa Tengah yang telah bersedia sebagai mitra penelitian.

\section{REFERENSI}

Al-Tabany, T.I.B. (2017). Mendesain Model Pembelajaran Inovatif, Progresif dan Kontekstual: Konsep, Landasan, dan Implementasinya pada Kurikulum 2013 (Kurikulum Tematik Integratif/KTI). Jakarta: PT Kharisma Putra Utama.

Ansari, J.A.N., \& Khan, N.A. (2020). Exploring the role of social media in collaborative learning the new domain of learning. Smart Learning Environments, $7 \quad$ (9): $\quad 1-15 . \quad$ DOI: https://doi.org/10.1186/s40561-02000118-7

Azzam, A. (2020). Smart Multimedia learning of ICT: role and impact on language learnners' writing fluency- Youtube online English learning resorsces as an example. Smart Learning Environments, 7 (24): $1-26 . \quad$ DOI: https://doi.org/10.1186/s40561-02000134-7

Dewi, D., \& Kaltsum, K. (2017). Peningkatan Kemampuan Pemecahan Masalah Peserta didik Melalui Penerapan Model Project Based Learning. Jurnal Penelitian Pembelajaran Fisika 8 (1): 813.

DOI: https://doi.org/10.26877/jp2f.v8i1.1331

Geni, P.R.L., \& Hidayah, I. (2017). Kemampuan Pemecahan Masalah Peserta didik pada Pembelajaran Problem Based Learning Bernuansa Etnomatematika Ditinjau dari Gaya Kognitif. Unnes Journal of Mathematics Education Research, 6 (1): 11-17.

Harjanto. (2008). Perencanaan Pengajaran. Jakarta: Rineka Cipta

Kusumam, A., Muukhidin., \& Hasan, B. (2016). Pengemangan Bahan Ajar Mata Pelajaran Dasar dan Pengukuran Listrik untuuk Sekolah Menengah Kejuruan. Jurnal Pendidikan Teknologi dan Kejuruan, 23 (1): 28-39. DOI: https://doi.org/10.21831/jptk.v23i1.9352 
Marsigit. (2016). Pengembangan Pembelajaran Matematika Berbasis Etnomatematika. Edu-Mat Jurnal Pendidikan Matematika, 3 (2): 180-192.

Murniati, S., Mulyono \& Kharis, M. (2017). Pembelajaran PBL Strategi Working Backward untuk Meningkatkan Pemecahan Masalah Matematik Peserta didik. Unnes Journal of Mathematics Education, 6 (1): 27 - 36.

Muzdalipah, I., \& Yulianto, E. (2015). Pengembangan Desain Pembelajaran Matematika untuk Peserta didik SD Berbasis Aktivitas Budaya dan Permainan Tradisional Masyarakat Kampung Naga. Jurnal Siliwangi, 1 (1): 63-74.

Rudyanto, H.E., Kartikasar A.H.S., \& Pratiwi, D. (2019). Etnomatematika Budaya Jawa : Inovasi Pembelajaran Matematika di Sekolah Dasar. Jurnal Bidang Pendidikan Dasar, 3 (2): 25-32. DOI: https://doi.org/10.21067/jbpd.v3i2. 3348

Setiyadi, D. (2018). Pengembangan Lembar Kerja Peserta didik (LKS) Matematika Lambang Bilangan Romawi Melalui Strategi TANDUR. Jurnal Dinamika Pendidikan Dasar, 10 (2): 93-100. DOI: https://doi.org/10.30595/dinamika.v10i2 .3894

Setiyadi, D., Zaenuri \& Mulyono. (2018). The Problem Based Learning Model With Etnomatematics Nuance By Using Traditional Games To Improve Problem Solving Ability. Jurnal of Primary Education, 7 (2): 179-186.

Setiyadi, D., Zaenuri., Mulyono., \& Dwidayati, N.K. (2018). The Traditional Games As A Means of Learning Resources Two Dimensional Figures In Primary School. Proceedings of the International Conference on Science and Education and Technology 2018 (ISET 2018). DOI: https://doi.org/10.2991/iset-18.2018.21
Shanti, W.N., \& Agus, M.A. (2016). Keefektifan Pendekatan Problem Solving dan Problem Posing dengan Setting Kooperatif dalam Pembelajaran Matematika. Jurnal Riset Pendidikan Matematika, 2 (1): 121-134. DOI: https://doi.org/10.21831/jrpm.v2i1.7155

Sumiarsi, N. (2015). Analisis Kompetensi Pedagogik dan Pengembangan Pembelajaran Guru SD Negeri 041 Tarakan. Jurnal Kebijakan Pengembangan Pendidikan, 3 (1) : 99104.

Supardi, U.S. (2012). Pengaruh Pembelajaran Matematika Realistik Terhadap Hasil Belajar Matematika Ditinjau dari Motivasi Belajar. Jurnal Cakrwala Pendidikan, 31 (2) : 244-255.

Supriyati, Zaenuri \& Sugiman. (2015). Keefektifan Model Pembelajaran Berbasis Etnomatematika terhadap Kemampuan Pemecahan Masalah Peserta didik Kelas VII. Unnes Journal of Mathematics Education, 4 (2) : 134141.

Tiagarajan, S., Semmel., \& Semmel. (1974). Intructional Development for Trainging Teachers of Exceptional Children A Sourebook. Indiana: ERIC.

Wardani, S. (2010). Pembelajaran Kemampuan Pemecahan Masalah Matemtika di SD. Yogyakarta: Kementrian Pendidikan Nasional Direktorat Jendral Peningkatan Mutu Pendidik dan Tenaga Kependidikan: Pusat Pengembangan dan Pemberdayaan Pendidik dan Tenaga Kependidikan (PPPPTK) Matematika.

Yusuf, M.W. (2010). Ethnomathematics (a Mathematical Game in Hausa Culture). International Journal of Mathematical Science Education Technomathematics Research Foundation 